\title{
Response to comment: Ungulate herbivory on wil- lows on Yellowstone's northern winter range
}

\author{
FRANCIS S. SINGER AND REX G. CATES
}

\begin{abstract}
Authors are research ecologist, National Biological Service, and scientist, Natural Resource Ecology Laboratory, Colorado State University, Ft. Collins 80523; professor, Department of Botany and Range Science, Brigham Young University, Provo 84602.
\end{abstract}

We concur with Wagner et al (1995), that ungulate browsing has an import effect on growth form, productivity, and survival of willows in northern Yellowstone National Park (hereafter YNP). We concur with Wagner et al. (1995) that elevation, precipitation, willow height, aboveground biomass production, and concentrations of secondary compounds covary in willow shoots on Yellowstone's northern ungulate winter range. We do not imply cause and effect between the climate change in northern YNP this century and the willow decline, nor do we reject the overabundant elk hypothesis (Singer et al. 1994). We present the case for a more complex, multi-causal situation, where interactions between elk abundance, climate change, fire, mammalian predators, and beaver abundance, might all influence the status and recruitment of willows. Singer et al. (1994) was intended as a paper to suggest a set of hypotheses that might explain the willow decline in YNP. We use cautionary phrases like may, likely, proposed, apparently, speculate, and circumstantial 27 times in Singer et al. (1995).

We disagree with Wagner et al. (1995) that elk densities in the area are inversely correlated with elevation (Coughenour and Singer 1995) and elk consume mostly a grass-sedge diet $(86 \%$ of the elk diet) and few willows ( $<0.1 \%$ of diet, Singer and Norland 1994).

Furthermore, ungulate browsing intensity is not inversely correlated with either elevation or precipitation. Biomass removed by ungulates during winter from tall willow stands, mostly by moose, exceeds that removed from suppressed willow stands 9fold, and that removed from intermediate stands by nearly 7 foldduring the winter. Ungulate browsing consumption $(\mathrm{kg} / \mathrm{ha}$ removed), is far greater in tall versus suppressed willows, the reverse of that contended by Wagner et al. (1995). Mean percent of current annual growth (CAG) removed 1988-93, averaged only slightly greater $(31 \%)$ in suppressed stands, compared to tall willows $(22 \%)$, and intermediate willows (26\%). These data indicate that suppressed willows at low elevations are at a serious disadvantage, in terms of growth potential, to cope with ungulate herbivory.

Wagner et al. (1995) state that woody plant species on the northern winter range have declined due to elk herbivory, and elk in northern YNP have been reduced to eating the least palatable forages, for example spruce (Picea engelmannii) and other conifers. The field evidence does not support their statement. No forages differed in elk diets compared between 1967-70 and
1986-88, a period when all northern range ungulates approximately tripled following cessation of artificial controls, and when the elk increase was 2.6 fold (Singer and Norland 1994). In fact, elk used aspen and conifer types significantly less during the recent period, and there was a tendency for less conifers in the elk diet during the recent period. Many upland woody shrubs have mostly increased, not decreased, over the past 5 decades (Singer and Renkin 1995). During this past century, until the large fires of 1988, there was a pattern of widespread conifer encroachment onto grasslands (Houston 1982), not a decline (Wagner et al. 1995). This appears to be largely due to fire suppression (Houston 1973, 1982).

It is grass forage that regulates elk, not willows and aspen (Houston 1982, Coughenour and Singer 1995). An already marginally-distributed shrub type--suppressed willows--has become highly palatable to elk whose numbers are regulated by something else. Wagner et al. (1995) disregard the fact that the grasslands of northern YNP, which are very important to elk regulation, are in good to excellent condition (Coughenour 1991; Frank and McNaughton 1992, 1993; Wallace and Macko 1993; Merrill et al. 1994; Coughenour et al. 1995; Reardon 1995; Lane and Montagne 1995; Singer 1995; Singer and Harter 1995), and aboveground production of grasses was stimulated by ungulate herbivory (Frank and McNaughton 1992, 1993), suggesting elk have not depleted their preferred food resources.

Wagner et al. (1995) question the significance of the climate change in YNP this century, and in doing so, thcy ignore a substantial volume of recent research and published literature. A climate change to increasing aridity in northern YNP this past century is well documented; summer temperatures increased $0.87^{\circ} \mathrm{C}$, and January-June precipitation decreased $61 \mathrm{~mm}$ (Balling et al. 1992a, 1992b). Fewer large floods have occurred during the last century, with the last large flood in 1918, and the last period of frequent floods in the 1870's (Meyer et al. 1992; Bingham and Meyer 1994) also due, in part, to a drier climate. Aging of aspen in northern YNP also verified a wetter period from 1870-90. All large canopy aspen stems sampled were generated during the wetter period of 1870-90 (Romme et al. 1995).

Considerable field evidence suggests drier conditions on sites occupied by suppressed willows. Willows are now co-dominant with dryland shrubs such as mountain big sagebrush (A. tridentata vaseyana) on many sites across the low and mid-elevations of the winter range. Almost no recruitment of willows is observed at 
the lower and mid-elevations of the winter range, including inside of exclosures, where the number of adult willows has declined $25 \%$ since 1958 (Singer 1995b). However, considerable numbers of willow seedlings and recruits occur at higher, wetter elevations. Elsewhere, birches and willows either sustain or increase their yield when removals of current annual growth are equivalent or greater than consumption rates on willows in YNP (Basset 1951; Lay 1965; Willard and McKell 1978; Wolff et al. 1983; Fox and Bryant 1984; Danell et al. 1985; Risenhover 1985).

We do not agree with the rare elk hypothesis for historic times in YNP (Kay and Wagner 1995; Wagner et al. 1995). Elk were greatly reduced by over harvesting for markets by 1871-77 (Schullery and Whittlesey 1992), and this period is not the standard by which to compare all future elk abundance. Elk increases were to be expected following this period. The overharvested elk were protected in the park starting about 1886 by the U.S. Army, wolves and other predators were controlled to protect ungulates, and elk were artificially fed during the winters (Skinner 1928; Wright and Thompson 1935; Houston 1982; Romme et al. 1995). The first aerial census of the herd was conducted in 1952, and any information prior to that must be regarded as conjectural and anecdotal. Neither a horseback count conducted over weeks, nor sporadic observations by early explorers constitutes scientific evidence of either absolute or relative elk densities. Houston (1982) and Schullery and Whittlesy (1992) concluded elk were abundant in the area historically, but Kay $(1990,1994)$, using some of the same historical, anecdotal, and uncontrolled observation data, concluded that elk were rare in the area in pre-Columbian times. We counter that pre-Columbian densities of elk will never be known accurately (computer models suggest only 8-20\% fewer elk with wolves present) Garton et al. 1990; Boyce 1993; Mack and Singer 1993). Wagner et al. (1995) assume, but do not prove, that elk have increased unnaturally.

Wagner et al. (1995) assume a more-or-less-equilibrium condition prior to establishment of YNP, and they make sweeping statements about elk numbers, and aspen and willow abundance prior to 1872 . The earlier park photos about 1870 set the stage for interpretations of all later changes (Houston 1973, 1982; Chase 1986; Kay 1990, Kay and Wagner 1995). But the period from 1870-90 was apparently an unusual time that followed an extensive fire sometime in the 1860 's, precipitation was relatively high, floods were larger and more frequent, wolves and beaver were still abundant, and ungulate numbers were relatively low (Houston 1973; Balling et al. 1992a, 1992b; Meyer et al. 1992; Romme et al. 1995). The early 20th century was also an unusual period without any large fires, with relatively dry climatic conditions, large beaver declines, extirpation of wolves, and higher densities of protected elk. Given this setting, one would expect some willow and aspen declines regardless of the number of elk and regardless of the Park policy on elk. Wagner et al. (1995) imply northern YNP should obtain a state of constant willow, constant beaver, and constant elk densities.

We disagree with Wagner et al. (1995) that there is no evidence suggesting lower secondary metabolites in suppressed willows increases their palatability to ungulates. We documented tannin declines of $15-17 \%$ in suppressed YNP willows which are near the threshold value of $5 \%$ above which African ungulates avoid browse (Cooper and Owne-Smith 1985). Even if tannin concentrations are unimportant, as Wagner et al. (1995) argue (but in contrast to Barry and Manley 1984 and Cooper and Owen-Smith
1985), phenolics are 64\% less in suppressed $S$. geyeriana and $41 \%$ less in suppressed $S$. wolfii; the declines in both compounds are unprecedented.

Wagner et al. (1995) assume a negative position and make 19 critical assertions of our work and YNP management of ungulates yet provide no new hypotheses or new suggestions for research. They do not suggest a density of elk or other management actions that would recover willow and aspen populations. Their underlying assumptions are that almost no wintering elk are appropriate for the system, yet the historical and paleontological literature indicates elk were common in the area historically (Houston 1982, Schullery and Whittlesey 1992; Bamosky 1995).

What to do about the "elk problem" in YNP? Wagner et al. (1995) offer no management options for dealing with the declines in willow-save perhaps to elimate elk altogether from YNP. There is good evidence that willow and aspen would be declining during the present period even with low browsing pressure, as born out by continued high herbivory of suppressed willows during the elk reductions of the 1960's. The only possibilities to stop declines in willows at low- and mid-elevations on the winter range seem to be: (1) elimination of the YNP elk, (2) extensive fence-building to create protective exclosures around all low elevation willow stands, and (3) reintroduction of wolves to reduce elk densities. YNP is in the process of doing the third option, while the first 2 options would have undesirable results. What other options are there? We appeal to Wagner et al. (1995) to provide more than just criticisms, and to also provide positive suggestions.

\section{Literature Cited}

Balling, R.C., Jr., G.A. Meyer, and S.G. Wells. 1992a. Relation of surface climate and burned area in Yellowstone National Park. Agr. For. Metero. 60:285-293.

Balling, R.C., Jr., G.A. Meyer, and S.G. Wells. 1992b. Climate change in Yellowstone National Park: is the drought-related risk of wildfires increasing? Clim. Change 22:35-40.

Barmore, W.J. 1980. Population characteristics, distribution and habitat relationships of six ungulates in northern Yellowstone National Park. Final Report. Yellowstone Park files.

Barnosky, E.A. 1995. Late Holocene mammalian fauna of Lamar Cave and its implications for ecosystem dynamics in Yellowstone National Park, Wyoming. In: P. Vohs, ed. Effects of grazing by native ungulates in Yellowstone National Park. A Rep. to the U.S. Congress, Nat. Park Serv., Denver, Colo.

Barry, T.N., T.R. Manley, and S.J. Duncan. 1986. The role of condensed tannins in the nutritional value of Lotus pedunculatus for sheep. Brit. J. Nutr. 55:123-137.

Bingham, M.K., and G.A. Meyer. 1994. Flood history since 1800 in relation to late Holocene climate change and stream incision, Yellowstone National Park. 46th Annu. Meet., Geol. Soc. Amer. Abstr. 26:5.

Boyce, M.S. 1993. Predicting the consequences of wolf recovery in Yellowstone National Park. pp. 234-269 In: R.S. Cook, ed. Nat. Park Serv. Sci. Monogr. No. 22. U.S. Dep. Int., Natl. Park Serv., Publ. Off., Denver, Colo.

Bryant, J.P., and P.J. Kuropat. 1980. Selection of winter forage by subarctic browsing vertebrates: the role of plant chemistry. Ann. Rev. Ecol. Syst. 11:261-285.

Cooper, S.M., and N. Owen-Smith. 1985. Condensed tannins deter feeding by browsing ruminants in a South African savanna. Oecologia 67:142-146.

Coughenour, M.B. 1991. Biomass and nitrogen responses to grazing of upland steppe on Yellowstone's northern winter range. J. Appl. Ecol. 28:71-82. 
Coughenour, M.B., F.J. Singer, and J.J. Reardon. 1995. The Parker transects revisted-long-term herbaceous vegetation trends on Yellowstone's northern winter range. pp. 73-84 In: D. Despain, ed. Plants and their environments: Ist Bienn. Sci. Conf. on the Greater Yellowstone Ecosystem. U.S. Nat. Park Serv., Trans. and Proc. Serv.

Coughenour, M.B., and F.J. Singer. 1995. Elk responses to precipitation, density and winter weather under natural regulation management in Yellowstone National Park. Ecol. Applic. (in press).

Despain, D.D. 1991. Yellowstone vegetation: consequences of environment and history in a natural setting. Roberts Rinehard, Boulder, Colo.

Frank, D.A., and S.J. McNaughton. 1992. The ecology of plants, large mammalian herbivores, and drought in Yellowstone National Park. Ecol. 73:2043-2058.

Frank, D.A., and S.J. McNaughton. 1993. Evidence for the promotion of aboveground grassland production by large herbivores in Yellowstone National Park. Oecologia 96:157-161.

Garton, E.O., R.L. Crabtree, B.A. Ackerman, and G. Wright. 1990. The potential impact of a retintroduced wolf population on the northern Yellowstone elk herd. pp. 359-391. In: Wolves for Yellowstone? Rep to the U.S. Congr., Vol. II, Yellowstone Nat. Park, Wyo.

Houston, D.B. 1973. Wildfires in northern Yellowstone National Park. Ecol. 54:1111-1117.

Houston, D.B. 1979. The northern Yellowstone elk-winter distribution and management. pp. 263-272. In: North American elk, ecology and management. M.S. Boyce and L.D. Hayden-Wing (cds.) Univ. of Wyoming, Laramie.

Houston, D.B. 1982. The northern Yellowstone elk: ecology and management. MacMillan Publ. Co., N.Y. 473 pp.

Kay, C.E. 1990. Yellowstone's northern elk herd: a critical evaluation of the "natural regulation" paradigm. PhD Diss., Utah State Univ., Logan. $490 \mathrm{pp}$.

Kay, C.E. 1994. Aboriginal overkill; the role of Native American in structuring western ecosystems. Human Nature 5:359-398.

Kay, C.E., and F.H. Wagner. 1995. Historical condition of woody vegetation on Yellowstone's northern range: a critical evaluation of the "natural regulation" paradigm. pp. 151-169 In: D.G. Despain, ed. Plants and their environments: Proc. of the 1st Bienn. Sci. Conf. on the Greater Yellowstone Ecosys. Tech. Rep. No. 93. Nat. Park Serv., Denver, Colo.

Lay, D.W. 1965. Effects of periodic clipping on yield of some common browse species. J. Range Manage. 18:181-184.

Lime, D.W., B.A. Koth, and J.C. Vlaming. 1993. Effects of restoring wolves on Yellowstone area big game and grizzly bears: opinions of scientists. pp. 306-326. In: R.S. Cook, ed. Ecological issues on reintroducing wolves into Yellowstone Nat. Park. Nat. Park Serv., Sci. Monogr. No. 22, Denver, Colo.

MacCracken, J.G., and L.A. Viereck. 1990. Browse regrowth and use by moose after fire interior Alaska. Northwest Sci. 64:110-118.

Mack, J.A., and F.J. Singer. 1993. Using POP-II models to predict the effects of wolf predation and hunter harvests on elk, mule deer, and moose on the northern renat pp. 49-74. In: R.S. Cook, ed. Ecological issues on reintroducing wolves into Yellowstone National Park. Nat. Park Serv. Sci. Monogr. No. 22. U.S. Dep. Int., Nat. Park Serv., Publ. Office, Denver, Colo.

Mack, J.A., and F.J. Singer. 1993. Predicted effects of wolf predation on northern range elk using POP-II models. In: R.S. Cook, ed. Ecological issues on reintroducing wolves into Yellowstone National Park, Nat. Park Serv., Sci. Monogr. No. 22. Denver, Colo.

Merrill, E.H., N.L. Stanton, and J.C. Hak. 1994. Responses of bluebunch wheatgrass, Idaho fescue and nematodes to ungulate grazing in Yellowstone National Park. Oikos 69:231-240.

Meyer, G.A., S.G. Wells, R.C. Balling, Jr., and A.J.T. Jull. 1992. Responses of alluvial systems to fire and climate change in Yellowstone National Park. Nature 357:147-150.

Neu, C.W., C.R. Byers, and J.M. Peek. 1974. A technique for analysis of utilization availability data. J. Wildl. Manage. 38:541-545.

Palo, R.T., K. Sunnerheim, and O. Theander. 1985. Seasonal variation of phenols, crude protein, and cell wall contents of birch (Betula pen$d u l a)$ in relation to ruminant digestibility. Oecologia 65:314-318.
Reardon, JaJ. 1995. Plant community response to grazing exclusion on Yellowstone's northern winter range; results of a 30-year study. In: P. Vohs, ed. Effects of grazing by native ungulates on Yellowstone's northern winter range. A Rep. to the U.S. Congr.

Risenhover, K.L. 1985. Intraspecific variation in moose preference for willows. Symp. Plant-Herbivore Interact., Snowbird, Utah.

Robbins, C.T., A.E. Hagerman, and. T.A. Hanley. 1987. Role of tannins in defending plants against ruminants: reduction in dry matter digestion? Ecol. 68:1606-1615.

Romme, W.H., M.G. Turner, L.L. Wallace, and J.S. Walker. 1995. Aspen, elk, and fire in northern Yellowstone National Park. Ecol. (in press).

Schullery, P., and L. Whittlesey. 1992. The documentary record of wolves and related wildlife species in the Yellowstone National Park area prior to 1882. pp. 1-174 In: Varley, J.D., and W.G. Brewster, eds. Wolves for Yellowstone? A report to U.S. Congress, Vol. IV. Research and Analysis. Natl. Park Serv., Yellowstone Natl. Park, Wyo.

Singer, F.J., and J. Norland. 1994. Niche relationships within a guild of ungulates following release from artificial controls, Yellowstone Nat. Park. Can. J. Zool. 72:1383-1394.

Singer, F.J., L. Mack, and R. Cates. 1994. Ungulate herbivory of willows on Yellowstone's northern winter range. J. Range Manage. 47:435-443.

Singer, F.J., and M.K. Harter. 1995. Comparative effects of elk herbivory and the fires of 1988 on grasslands in northern Yellowstonc Nat. Park. Ecol. Appl. (in press).

Singer, F.J. 1995. Effects of grazing by ungulates on upland bunchgrass communities of the northern winter range of Yellowstone National Park. Northwest Sci. (in press).

Singer, F.J., and R.A. Renkin. 1995. Effects of browsing by native ungulates in shrubs in big sagebrush communities in Yellowstone National Park. Great Basin Natur. (in press).

Wagner, F.H., R.B. Keigley, and C.L. Wambolt. 1995. Ungulate herbivory of willows on Yellowstone's northern winter range: Comment to Singer et al. (1994). J. Range Manage. 48:475-477.

Willard, E.E., and C.M. McKell. 1978. Responses of shrubs to simulated browsing. J. Wildl. Manage. 42:514-419.

Wolfe, M.L., W.H. Babcock, and R.M. Welch. 1983. Effects of simulated moose browsing on Drummond's willow. Alces 19:14-35. 